him in 1882. For several years he was one of the editors of the Quarterly Journal of Microscopical Science. In the summer of 1882 Balfour went to Switzerland to recuperate from an attack of typhoid fever. $\mathrm{He}$ and his guide were killed, probably on July 19, while attempting to climb a virgin peak on Mont Blanc. His tragic death at the early age of thirty-one robbed the world of science of one of its most imaginative, original, attractive and promising workers.

Institute of Navigation : Medal Awards for 195I

The Gold Medal for 1950-51 of the Institute of Navigation has been awarded to $\mathrm{H}$. C. Pritchard for valuable contributions to navigation made over a number of years in the field of airborne navigation equipment. In $1939 \mathrm{Mr}$. Pritchard formed the Navigation Section at the Royal Aircraft Establishment, and it was in a large measure due to his personal guidance that practical solutions were found to many of the air navigator's problems. Mr. Pritchard's team successfully developed the distantreading and gyro-magnetic compasses, the air mileage unit, air position and ground position indicators, the drift recorder, the astrograph and the astro-compass. Later during the War, Mr. Pritchard was given responsibility for the formation of an experimental unit to deal with problems of blind approach and landing, and important advances were made in the art of all-weather flying.

Bronze Medals, for the best paper to be published in any year in the Institute's Journal, have been awarded to R. F. Hansford (development of shipborne navigational radar), C. S. Durst and N. E. Davis (jet streams and their importance to air navigation), and Captain F. J. Wylie, R.N. (ret.) (radar and the rule of the road at sea).

Lord Cherwell, P.C., F.R.S. : Paymaster-General

ON July 5 in the House of Lords, Lord Cherwell made a vigorous attack on the way in which research on, and development of, atomic energy was being conducted in Great Britain. Lord Cherwell has now been appointed to the office of Paymaster-General in the new Government headed by Mr. Winston Churchill, and has been made responsible for the supervision of research and production in connexion with atomic energy, and also for the Prime Minister's statistical branch. It is worth recalling some of the points made by Lord Cherwell in the House of Lords debate. He referred to the impending retirement of Lord Portal from the post of director of atomic energy, and urged a complete change of organization. Civil Service methods, he said, were inadequate for the task, and the scientific men and engineers required were not forthcoming because they hesitated to commit themselves in a service where their work would always be subject to Civil Service administration. He asked for the transfer of work on atomic energy from the Ministry of Supply, which hitherto has been responsible for it, "to a special organization under the direct control of the head of the Government". His present appointment suggests that Lord Cherwell will now be able to put his views into practice, though such drastic changes in the control of a large body of scientific workers and others must clearly take a little time. Since he has a seat in the Cabinet and he is to have an office at 11 Downing Street, he will have easy access to the Prime Minister. Lord Cherwell is a man of energy and determination, and can be counted upon to see that atomic energy research and development in Great Britain receive the attention so vital a subject warrants.

\section{Rockefeller Grant for Chemistry in the University of Oxford}

THE Rockefeller Foundation of New York has made a grant to the University of Oxford of $£ 10,000$, to be expended over four years, for the Dyson Perrins Laboratory in aid of research in organic chemistry sponsored or directed by the Waynflete professor of chemistry, Sir Robert Robinson. The chief topics of such investigations at the present time are: (1) degradative and synthetic studies of alkaloids, plant colouring matters, and certain other natural products ; (2) study of the lipins of tubercle bacilli, especially the fatty-acid constituents; (3) isolation of a differential growth-inhibiting factor present in malt and wheat-middlings ; (4) synthesis of steroids other than cortisone (this latter is covered by a grant from the Nuffield Foundation); (5) general studies of organic chemical reactions.

\section{The Battelle International Institute}

The Battelle Institute, Columbus, Ohio, the wellknown American industrial research foundation, proposes to establish an international industrial research institute to serve European industry, on a non-profit basis, through science and technology. The new body, to be known as the Battelle International Institute, will establish research investigations in existing research institutes of Europe and in European universities and technical schools. It will also operate its own laboratories on the Continent. As with the parent organization, financial support for these activities will be derived from industrial sponsorship, from endowment, and from income from patents owned by the Battelle Institute. It will conduct research in the fields of applied chemistry and physics, metallurgy, fuels, ceramics, electronics, theoretical and applied mechanics, the engineering sciences and agriculture. Mr. John S. Crout, for many years assistant director of the Battelle Institute, has been appointed executive director of the new Institute.

\section{Cultural Anthropology of the Rodiyas of Ceylon}

THe Rodiyas of central and southern Ceylon are a primitive tribal group, fifteen hundred strong, who have become partly incorporated in Sinhalese society a a caste of drum-makers and beggars. A brief account of them by M. D. Raghavan, "Cultural Anthropology of the Rodiyas" (Ethnological Survey of Ceylon, No. 1: Spolia Zeylanica, 26, Pt. 1, December 1950), is the first of a series of studies of the lower castes in Sinhalese society to be undertaken as part of the Ethnological Survey of Ceylon: It describes Rodiya myths of origin; habitat and village organization; daily life, crafts and methods of begging ; rites at birth, marriage and death ; and peculiarities of Rodiya dialect. Suggestions are offered for Rodiya education and for their further assimilation into Buddhist society. Of interest is the Rodiya myth of descent from Navaratne Valli, a Sinhalese princess who lost her caste through eating human flesh, and the comparison drawn between this mythical ancestress and the Kerala goddess Bhagavadi.

\section{Catalogue of Kenya Timbers}

The Government of Kenya has published a "Catalogue of Kenya Timbers", prepared by S. H. Wimbush, of the Forest Department (pp. 69; 